\title{
The Influence of Learning Activities, Family Environment, and Study Interests on the Quality of Learning PKWU (Craft and Entrepreneurship)
}

\author{
Rahmawati $^{1}$, Susi Evanita ${ }^{2}$
}

\author{
1, 2 Universitas Negeri Padang, Padang, Indonesia \\ *Corresponding author. Email: mpderahmawati26@gmail.com
}

\begin{abstract}
This study aims to analyze and see the effect of learning activities, family environment, and learning interest on the learning quality of PKWU (workshops and entrepreneurship). This type of research is ex post facto with a population of 306 people. The sampling technique used proportional random sampling with a sample of 173 people. The analysis technique used is Multiple Regression Analysis. The results of this study indicate that: 1) Learning Activities have a positive and significant effect on the learning quality of PKWU (Craft and Entrepreneurship), 2) Family Environment does not have a positive and significant effect on the learning quality of PKWU (Craft and Entrepreneurship), 3) Learning Interest has a positive and significant effect. significant towards the quality of learning PKWU (Craft and Entrepreneurship) 4) Learning Activities, Learning Environment, and Learning Interests together have a positive and significant effect on the quality of PKWU learning (Craft and Entrepreneurship).
\end{abstract}

Keywords: Learning activities, Family environment, Learning interest, Learning quality.

\section{INTRODUCTION}

One of the efforts made by the government to produce quality human resources and adapt to the times is to develop curriculum. [1]The current curriculum used is the 2013 curriculum, where the government has made several revisions to improve it. One of the advantages, creative, and innovative in solving problems faced by students, even though this curriculum still needs to be developed and improved. The 2013 curriculum emphasizes and skills.

The updating of the 2013 curriculum learning process lies in learning that emphasizes the modern pedagogical dimension, namely using a scientific approach. The scientific approach is a form of learning activity. Learning that emphasizes learning activities will be more meaningful and lead students to memorable learning experiences. Learning activities can stimulate students to be actively involved in learning, so that it can stimulate students' brains to think critically and solve problems that lead to increased learning outcomes when assessments are carried out, and the success of a learning process (learning quality).

Learning activities are activities or actions both physically and mentally carried out by individuals to build knowledge and skills within themselves in learning activities. Learning activities need to be increased in learning, including in PKWU (Craft and Entrepreneurship) learning. The principle of craftsmanship has an educational goal and foundation in order foster sensitivity to 2013 curriculum. Indicators that can be used as benchmarks for the success of a subject in producing quality students are reflected in quality learning achieved or value earned. PKWU learning achievement is not only from written scores but also practical test scores. 
Based on the results of the documentation obtained from PKWU teachers, it is seen that there are still some This is a fourth level heading [2]. You can replicate it where suitable. Classes that have not reached the minimum completeness criteria (minimum completeness criteria), namely the value of 75 . This shows that the quality of student PKWU learning is still low. This can happen because there are obstacles for students in learning.

The obstacles in question can be in the form of internal factors or external factors. Internal factors are physical conditions, psychological conditions (interests, intelligence, talents, motivation, attitudes, habits, emotions, and self-adjustment). External factors, namely environmental factors (natural environment, socio-cultural environment) and instrumental factors[3].

Interest in learning is one the internal factors can learning outcomes. [5] A level of attainment of abilities and competencies is largely determined by the interest of students in the subject. Students who have an interest in learning are expected to achieve optimal learning achievement. [7] In addition to learning interest, the family environment is also considered an external factor that can affect student learning outcomes. The family environment is everything that is in a small social group that functions to protect each of its members consisting of father and mother who have blood relations, love between them.

Based on background, author are interested a conducting a research entitled "The Effect of Learning Activities, Family Environment, and Learning Interests on the Quality of Learning PKWU".

\subsection{Research hypothesis}

The hypotheses in this study are asfollows:

Ha1: Learning activities have a positive and significant effect on the quality of PKWU learning.

Ha2: Family environment has a positive and significant effect on the quality of PKWU learning.

Ha3: Interest in learning has a positive and significant effect on the quality ofPKWU learning

Ha4: Learning activities, family environment, and learning interests together have a positive and significant effect on the quality of PKWU learning.

\section{METHODS}

\subsection{Research Design}

The research design used is ex post facto research, which is a study conducted to examine events that have occurred and then draw back to determine the factors that can cause these events. This type of research uses a quantitative approach, to determine the effect of learning activities, family environment and interest in learning on the quality of learning PKWU (Craft and Entrepreneurship). This research was conducted at SMAN $1 \mathrm{Kec}$. Akabiluru District Fifty Cities. The implementation of this research was carried out in July-August 2020.

\subsection{Operational Definition Variable}

a) Learning Quality is a achievement of the initial learning objectives including art learning, in achieving these goals in the form of increasing knowledge, skills and developing attitudes of students through the learning process in the classroom.

b) Learning activities are carried out by students during the learning process. The activities of students during learning reflect the motivation or desire of students to learn

c) In the family environment, a child gets love, attention, guidance, exemplary and encouragement from parents to be able to develop their abilities for future development.

d) Interest in Learning is a high motivation or enthusiasm in terms of focusing attention on learning activities through interaction with the environment and will lead to changes in behavior.

\subsection{Research Instrument Test}

\section{1) Validity Test}

Arikunto states a "Validity is a measure that shows the levels of validity or validity of an instrument" [2]. According to Arikunto the Pearson correlation formula. After $r$ count is obtained, then $r$ count is compared with $r$ table. If $r$ count $\geq 0.350$ then the statement item is valid and can be used, and vice versa if $r$ count $<0.350$ then the statement is invalid and will not be reused.

\section{2) Reliability Test}

Reliability test is an instrument that is used as a data collection tool. This reliability test aims to obtain an instrument that can truly be trusted. To test the reliability of the instrument, the Cronbach formula is used as follows: 


$$
\alpha=\left(\frac{K}{K-1}\right)\left(\frac{s_{r}^{2}-\Sigma s_{i}^{2}}{s_{x}^{2}}\right)
$$

The instrument is said to be reliable if $r$ count $>$ $r$ table and vice versa if $r$ count $<r$ the instrument 2.1.4 Classic Assumption Test

1) Normality Test

Table 1. Normality Test One-Sample Kolmogorov-Smirnov Test table is said to be unreliable, or the calculated $r$ value is consulted with the interpretation table $r$ provided that it is reliable if $r$ counts 0.600 .

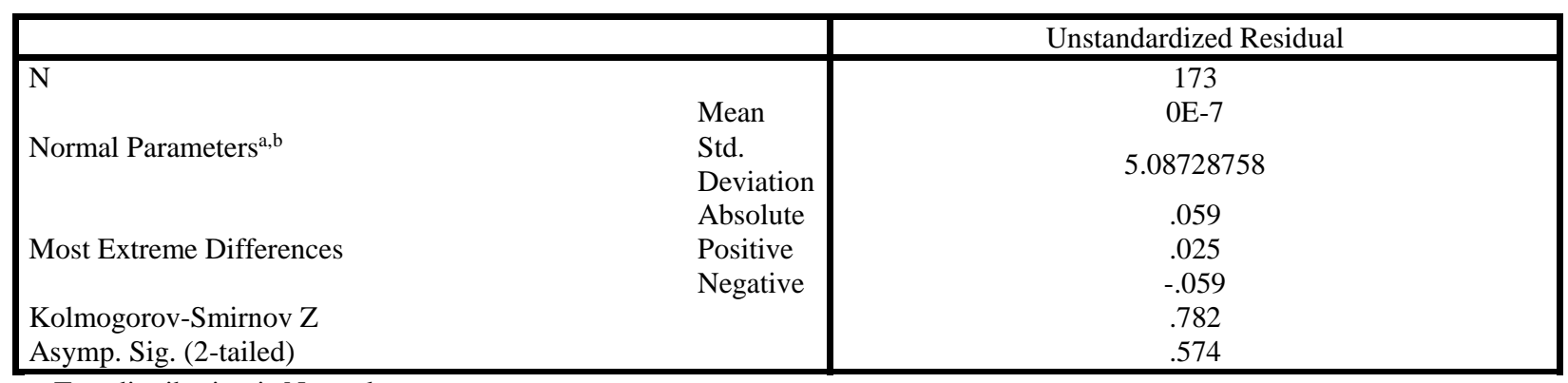

a. Test distribution is Normal.

b. Calculated from data.

The table 1, shows the results of a normality test of all research variables have a significance value of more than 0.574 at ( $\mathrm{sig}>0.05$ ), so it can be concluded that the research data residuals arenormally distributed

\section{2) Multicollinearity Test}

According to Ghozali to detect the presence or absence of multicollinearity in the regressionmodel, it can also be seen from (1) the tolerance value and its counterpart (2) Variance Inflation Factor (VIF).

Based on the results of the multicollinearity test, it can be seen in the VIF value of the variables, namely learning activities, family environment, interest in learning each value is $2.379 ; 1,735 ; 2,599$; and VIF value of the variable shows a number less than 10 or VIF $<10$ and a tolerance value greater than 0.10

\section{3) Autocorrelation Test}

The autocorrelation test is to see whether there is a correlation between a period $t$ and the previous period (t-1). In this study, researchers used the run test method to test whether the data were free of autocorrelation symptoms

4) Heteroscedasticity Test

Heteroscedasticity test aims to test whether in the regression model there is an In a Quality. If the residual variance from one observation to

\section{RESULTS AND DISCUSSION}

Sugiyono is a regression equation that involves the relationship between two or more variables [7]. Multiple linear regression is used to determine the effect a changes from one independent variable on the dependent variable. Multiple linear regression model as follows [7]:

$$
\hat{\mathrm{Y}}=\mathrm{a}+\mathrm{b} 1 \mathrm{X} 1+\mathrm{b} 2 \mathrm{X} 2+\mathrm{b} 3 \mathrm{X} 3
$$

Information:

$$
\begin{aligned}
& Y=\text { quality of learning } \\
& a=\text { constant } \\
& b=\text { regression coefficient } \\
& X=\text { Independent variable } \\
& e=\text { Error }
\end{aligned}
$$

Based a calculation results, the multiple linear regression equation is obtained as:

$$
\hat{\mathrm{Y}}=3,262+0,356 \mathrm{X} 1+0,040 \mathrm{X} 2+1,132 \mathrm{X} 3
$$

Based on the resulting output. model summary, the correlation coefficient value is 0.860 . This correlation is classified as a strong correlation. The coefficient of determination can be seen from the R square of 0.740 or $74 \%$. This shows that the independent variables (X1, $\mathrm{X} 2, \mathrm{X} 3$ ) can explain the dependent variable (learning quality) by $74 \%$ and the remaining $26 \%$ is explained by other variables not included in this study.

\section{1) The effect of learning activities on the quality} of PKWU learning

Based on the results table $(4,317>1,654)$. The regression model using a mathematical model can be described as follows: $\hat{\mathrm{Y}}=3.262+0.356 \mathrm{X} 1$. This regression model means that it is estimated that every 1 unit increase in the $\mathrm{X} 1$ score or learning activity will increase 0.356 units in $\mathrm{Y}$ or the learning quality variable. This shows that the higher the learning activities carried out by students, the higher the quality 
of PKWU learning, and conversely low learning activities will cause the quality of learning to be low. Things that need to be considered are that the teacher must always increase learning activities for students by developing active and fun learning models. Always give awards to students who have good learning quality, as well as provide encouragement and encourage students who do not have good learning quality.

Based on the calculation results show that learning activities affect the learning outcomes of students in class X Accounting at SMK Negeri 1 Singaraja in the academic year 2013/2014. This can be seen from the $t$ value of 5.742> t table 1.658 or the significant count $0.000<\alpha 0.05$. So the hypothesis which states that there is a positive and significant influence between learning activities on student learning outcomes is proven and acceptable.

\section{2) The influence of the family environment on the quality of PKWU learning}

After testing the hypothesis through the results of the $t$ test, it is found that the positive $t$ value of 0.603 is smaller than t table 1, 654 and is significant at 0.547> 0.05 , it can be concluded that hypothesis 2 is rejected, which means that the family environment variable has no positive effect on quality learn partially. The regression model using a mathematical approach can be described as follows: $\hat{\mathrm{Y}}=3.262+0.040 \mathrm{X} 2$. The regression model means that it is estimated that every 1 unit increase in the $\mathrm{X} 2$ score or family environment will increase 0.040 units in $\mathrm{Y}$ or the learning quality variable. It can be seen that the family environment does not really influence the quality of PKWU student learning, whereas according to Gunarso suggests that "in the field of education, the family is the main source of education, because all knowledge and human intellectual intelligence are obtained first from parents and own family members". Because it is motivated by the education of parents who are not parents who are highly educated, and also presumably because of the lack of role of parents towards their children [4]. Some parents of students still ignore their children's learning at home, turn on the television when children study at home, do not ask questions about learning outcomes at school, are not sufficient in completing their children's learning. This is because parents have entrusted their children's educational affairs to school.

The $t$ value is 1.462 and the $r$ count is 0.145 . The family environment has no effect on student achievement. This is because the family environment is less supportive of student learning activities at home. Therefore, the family should give great understanding and attention so that children are more motivated in learning so that the learning outcomes achieved can be optimal. Good relations between family members are also needed so that children feel comfortable while studying at home so that they can achieve optimal learning outcomes.

\section{3) The Effect Effect of Interest in Learning on the Quality of PKWU Learning}

Interest in Learning has a positive and significant effect on the quality of PKWU learning. This is in accordance with the hypothesis testing carried out through the results of the $t$ test, the value of $t$ count $>t$ table (9.9914> 1.654), so it can be concluded that interest in learning has a positive effect on the quality of learning and the hypothesis is accepted.

The regression model using a mathematical model can be described as follows: $\hat{\mathrm{Y}}=3.262+1.132 \mathrm{X} 3$. The regression model means that it is estimated that every 1 unit increase in the X3 score or interest in learning will increase 1.132 units in $\mathrm{Y}$ or the learning quality variable. These results indicate the learning quality, and conversely, the lower the student's learning interest, the lower the learning quality. In other words, students who have high interest in learning will also easily achieve the desired goal, namely improving the quality of PKWU learning.

\section{CONCLUSIONS}

The results of this study indicate that: 1) Learning Activities have a positive and significant effect on the learning quality of PKWU (Craft and Entrepreneurship), 2) Family Environment does not have a positive and significant effect on the learning quality of PKWU (Craft and Entrepreneurship), 3) Learning Interest has a positive and significant effect. significant towards the quality of learning PKWU (Craft and Entrepreneurship) 4) Learning Activities, Learning Environment, and Learning Interests together have a positive and significant effect on the quality of PKWU learning (Craft and Entrepreneurship).

This research contributes to schools in overcoming the problems faced. Especially for teachers in carrying out PKWU (Workshop and Entrepreneurship) learning in order to improve the quality of student learning by carrying out learning activities that can provoke students' interest in learning and be actively involved in learning, so that the quality of PKWU learning can increase.

\section{REFERENCES}

[1] Apriliawati.(2011). Application of ARCH Motivation Strategies in Cooperative Learning Type STAD. Surabaya: UNESA

[2] Arikunto, S. Research Procedure Pratical Approach. Jakarta: Rineka Cipta (2014).

[3] Conny Semiawan.Family Education in a Global Era. Jakarta: PT. Preenhalindo. .(2010). 
[4] Ghozali, Imam. Multivariate Analysis Application with SPSS Program. Fourth PrinTIS Semarang: Diponegoro University Publishing Agency. (2006).

[5] Gunarso,S.Adolescent psychology. Jakarta: AndiOffset. (1985).

[6] Slameto. Learning and the Factors That Affect It. Jakarta: PT RinekaCipta. (2013).
[7] Sugiyono. Qualitative and Quantitative Research Methods $R \&$ D . Bandung: Alfabeta. . (2007). 